Spring 2017

\title{
Under Western Eyes and Terrorism Today
}

Joyce Wexler

Loyola University Chicago, jwexler@luc.edu

Follow this and additional works at: https://ecommons.luc.edu/english_facpubs

Part of the English Language and Literature Commons

\section{Recommended Citation}

Wexler, Joyce. Under Western Eyes and Terrorism Today. Conradiana, 59, 1: 53-74, 2017. Retrieved from Loyola eCommons, English: Faculty Publications and Other Works, http://dx.doi.org/10.1353/

cnd.2017.0003

This Article is brought to you for free and open access by the Faculty Publications and Other Works by Department at Loyola eCommons. It has been accepted for inclusion in English: Faculty Publications and Other Works by an authorized administrator of Loyola eCommons. For more information, please contact ecommons@luc.edu.

\section{(c) $($ ) $(9)$}

This work is licensed under a Creative Commons Attribution-Noncommercial-No Derivative Works 3.0 License.

(c) Texas Tech University Press, 2017. 


\title{
Under Western Eyes and Terrorism Today
}

\author{
JOYCE WEXLER
}

LOYOLA UNIVERSITY CHICAGO

Keywords: Joseph Conrad, Under Western Eyes, terrorism, counterterrorism

\begin{abstract}
Although historians and literary critics discount the practical information about terrorism in Under Western Eyes, social science research corroborates Conrad's account of terrorism and counter-terrorism in nineteenth-century Russia. According to this research, terrorists are indistinguishable from the general population until they decide to join a terrorist group, and the best way to prevent terrorism is to study the specific mindset of terrorist groups. The novel animates these findings in its depiction of fundamental similarities between the bomber and the informer. Haldin and Razumov pursue community as well as autonomy, although their paths are quite different. The novel not only presents a critique of terrorism and counter-terrorism, revolution and reform, autocracy and democracy, but also offers alternatives to the violence of the state and its opponents. While Conrad was skeptical of all ideologies, he believed that his method of presenting competing ideas fostered hope.
\end{abstract}

Joseph Conrad's political novels seem so prescient that journalists have turned to them to understand today's terrorists. For example, in The New York Times Book Review of September 11, 2005, Tom Reiss called Under Western Eyes (1911) "the true classic of terrorism." It was written "during the first great terrorist wave of modern times" and "it puts us into the psychic world of the terrorists, a place where violent action is the ultimate proof of sincerity, it is 
dazzling, unique. We see the cult of the suicide bomber in the mystic terrorists of 100 years ago" (35). Nevertheless, literary critics and historians usually deny that there is any useful information about terrorism in the novel. Although they search for Conrad's political beliefs in his fiction, they discount his knowledge of political events. This tendency to separate literary meaning from practical information needlessly reduces the novel's current significance. We want to know more about terrorism, and we read the novel with recent attacks in mind. As a result, we are likely to be less sympathetic to the revolutionaries than earlier critics were. Haldin, the bomb-throwing revolutionary, was praised because he fights autocratic Russia, but Razumov, the student who leads the police to the terrorist, was condemned because he betrays a fellow student. Recent social science research supports other interpretations. This research indicates that terrorists are indistinguishable from the general population until they decide to join a terrorist group. Therefore, attempts to develop a psychological profile of terrorists fail. The best way to prevent terrorism, experts argue, is to study the specific mindset of terrorist groups and learn their immediate plans. Under Western Eyes reinforces these findings by examining revolutionary violence in nineteenth-century Russia, where terrorism as we know it was theorized. Conrad describes the social forces and ideologies that motivate each character as well as the underlying similarities between the bomber and the informer.

In The Age of Terrorism, the historian Walter Laqueur illustrates the way Conrad's account of terrorism has been relegated to strictly literary significance. Laqueur sees Under Western Eyes as a story of betrayal rather than terrorism, arguing that as a novelist Conrad has nothing useful to tell us about political violence because he is interested in characters' personal motives. Laqueur warns that Conrad's focus on the theme of betrayal provides no empirical information:

Betrayal is the main motive in Joseph Conrad's Secret Agent and Under Western Eyes and countless other novels. It is of course true that few, if any, terrorist groups escaped defectors and traitors in their ranks. However, the heavy emphasis on treason to the detriment of other motives is bound to distort the general picture. It may result in a brilliant work of fiction, but then the novelist is preoccupied with the fate of the individual, whereas the historian pays more attention to social and political movements. (175)

Laqueur, however, ignores the ways that Conrad embeds "the fate of the individual" in "social and political movements." As Conrad himself explains in his 
1905 essay on "Autocracy and War," "the psychology of individuals, even in the most extreme instances, reflects the general effect of the fears and hopes of the time" (34). ${ }^{1}$ In fact, Laqueur makes the same point in a discussion of The Secret Agent:

Everyone is impelled by considerations transcending the self as well as by motives of a personal character. Fiction cannot offer a master key to the soul of the terrorist; the most one can hope for is to detect certain common patterns in the character and mental make-up of the dramatis personae, who acted as a group at a certain time and place. (195)

The "most one can hope for" is not insignificant, and the "common patterns" in Conrad's fiction are not only situated in a specific time and place, but they are consistent with recent findings of contemporary experts on terrorism.

Contesting popular assumptions, current social science research corroborates Conrad's account of the social, political, and personal factors that lead to terrorism. In 1999 the Federal Government Research Institute published a comprehensive report by Rex A. Hudson on "The Psychological and Sociological Causes of Terrorism." Although the report is now almost twenty years old, it deserves respect. After all, it accurately predicted that al-Qaida would hijack airplanes to attack government buildings (7), and subsequent studies have confirmed its findings. Hudson's survey of political, religious, and ideological groups refutes popular explanations of terrorism. After reviewing the familiar hypotheses that the terrorist is "the lunatic, the loner, the threatener, the hater" (44), the report concludes that it is impossible to identify a terrorist personality (30). Hudson points out that empirical research on various organizations indicates that terrorists are like everyone else until they join a terrorist organization (31). The ideology of the group transforms the individuals who join it. Profiling not only targets innocent people, but it distracts police from truly dangerous suspects. ${ }^{2}$

On the other hand, Hudson's report states, the mindset of terrorist groups can be profiled. There are constants in terrorist organizations, not in the psychology or social background of their members. Hudson observes that such organizations satisfy the general desire for both community and "revolutionary heroism" (37). People who join terrorist groups are usually young, and they are often friends before they become conspirators. Typically, the leader imposes severe discipline and discourages all outside contact. Members are required to prove their commitment to the group's ideology by performing tests, including acts of violence. To understand any group's mindset, the report advises, one must study its particular goals within "its own cultural, economic, political, 
and social context" (64). Instead of asking who becomes a terrorist, we should ask what terrorist groups intend to do. ${ }^{3}$

In light of this research, Under Western Eyes deserves Reiss's accolade. The novel dramatizes experts' findings in all their complexity, a complexity that critics often ignore. Under Western Eyes is a "classic of terrorism" because it replaces popular stereotypes with individualized characters located in the specific historical conditions that led to violence in Russia. Like contemporary experts, Conrad shows that it is impossible to construct a psychological profile of terrorists because they are different from each other and-except for their willingness to use violence-no different from everyone else. Each character has distinct reasons for his or her decision to join or oppose a political faction. The revolutionaries' common opposition to autocracy encompasses a wide range of individuals. Their "mindset" brings them together but does not eliminate their differences. Nor do their individual personalities predict their behavior. Haldin is adored by his mother and sister and admired by fellow students. Razumov is the illegitimate son of an aristocratic father and depends on his academic ability to win a place in society. He hopes that writing a prize essay will lead to "an administrative appointment of the better sort" (17). Since Razumov is friendless whereas Haldin is secure, we might expect Razumov to be the terrorist. Nevertheless, it is the more fortunate man who assassinates a government minister.

In addition to individualizing the revolutionaries, Conrad portrays underlying similarities among them. Both the bomber and the informant are students who oppose the autocratic regime, though Haldin works for revolution while Razumov advocates gradual reform. Haldin risks his life for his political cause, but his decision to throw a bomb at the minister's carriage is the act of an autonomous individual who expects to be remembered for his courage. Razumov protects his prospects for a career, but he is also a patriot. As Alex Houen notes, "Just as Razumov wishes to become, above all, a representative of the nation, so Haldin talks of his soul as working on behalf of Russia itself" (73). Despite their different choices, both express a fundamental desire for solidarity and autonomy, the goals that Hudson names community and heroism.

\section{THE CRITICAL CONSENSUS}

The critical tradition, however, has obscured the ways Haldin and Razumov are similar. Since the novel appeared, most critics have regarded the two students as antithetical figures, admiring Haldin and despising Razumov. Although Haldin is the bomber, he is idealized as a self-sacrificing patriot. 
Razumov helps the police, yet he is disparaged as an informant. An unsigned review in the Pall Mall Gazette of October 11, 1911, titled "Betrayal," set the tone: "We are revolted by Razumoff's betrayal of his fellow-student (though Haldin's crime merited the swift and degrading execution that was its punishment), for Haldin had sought refuge in Razumoff's rooms and had confessed to his crime under the conviction that his host was, like himself, a Nihilist" (227). In The English Review Ford Madox Hueffer called Razumov a "traitor" (242). A mid-century article by Robert F. Haugh on "Conrad and Revolution" described Razumov as "an archconservative young student in St. Petersburg, who betrays a fellow-student hiding in Razumov's room after the successful assassination of a Czarist official" (274). Contrasting the two students, Frederick R. Karl declared, "Thus Razumov is even more than usually interested in self, while Haldin, on the contrary, has just committed his most selfless act for the revolutionary cause" (317). These claims reflect the political sympathies of the critics. Antipathy toward Russia is evident in the widespread opinion that Haldin's act is warranted by the evils of autocracy, evils that Conrad himself lambastes in "Autocracy and War." Although these critics praise Haldin's self-sacrifice and condemn Razumov's selfishness, by today's standards Razumov is a model citizen. He obeys the mandate, "If you see something, say something."

John Hagan is a welcome voice of dissent from what he calls the "orthodox" view that the "betrayal itself was prompted by Razumov's culpable egoism and selfishness" (310). Notwithstanding the impressive list of critics who take this position, including Thomas Moser, Albert J. Guerard, Leo Gurko, Ted E. Boyle, and Frederick R. Karl (310-11), Hagan argues, "Razumov loathes the situation which the betrayal has placed him in, but he never expresses any doubt about the necessity of that betrayal" (314). He feels neither guilt nor remorse for leading the police to Haldin. Citing the "Author's Note" of 1920 in which Conrad describes Razumov as "an ordinary young man, with a healthy capacity for work and sane ambitions," Hagan claims that Razumov's "concern for his personal future is not to be regarded as mere vanity, selfishness, or cold egotism" (316). Razumov knows that to "keep out of the fray-to avoid the extremism of either reaction or revolution-is the only course by which he can see his way clear to a future of any distinction, not to mention mere survival" (316-17). Hagan accepts Razumov's reasons for denying that he betrayed Haldin and attributes Razumov's downfall to the crime he almost committed-deceiving Haldin's sister in revenge for Haldin's destruction of his future career (320). Razumov's moral dilemma is not whether or not to turn Haldin in but whether or not to let Natalia and the other expatriates in Geneva continue to believe that he helped Haldin. 


\section{READING UNDER WESTERN EYES TODAY}

Hagan's 1969 defense of Razumov may be more acceptable now that terrorism is so widely feared. Instead of sympathizing with Haldin, readers are more likely to hear echoes of recent terrorists' rationales in his justification of his violent act. As Martha Crenshaw observes, “Terrorists usually show acute concern for morality, especially for sexual purity, and believe that they act in terms of a higher good. Justifications usually focus on past suffering, on the glorious future to be created, and on the regime's illegitimacy and violence, to which terrorism is the only available response" ("Causes of Terrorism" 395). Similarly, Haldin tells Razumov that the assassination of a government minister was a personal sacrifice for the sake of his country: "You suppose that I am a terrorist, now-a destructor of what is. But consider that the true destructors are they who destroy the spirit of progress and truth, not the avengers who merely kill the bodies of persecutors of human dignity. Men like me are necessary to make room for self-contained, thinking men like you'” (23). In addition, Haldin affirms the purity of his intentions. He claims the virtues of "self-sacrifice, of martyrdom, of conviction, of faith-the labours of the soul" (24). He calls on a mystic patriotism to redeem him for having killed bystanders who were near the minister's carriage: “The Russian soul that lives in all of us. It has a future. It has a mission, I tell you, or else why should I have been moved to do this-reckless-like a butcher-in the middle of all these innocent people-scattering death- I! I! . . I wouldn't hurt a fly!” (25). Haldin claims that his violence is principled, necessary, and beneficial to the Russian nation. ${ }^{4}$

At the same time, Haldin takes pride in his act. When he explains why it is important for him to escape, egotism replaces altruism: "Men like me are rare. And besides, an example like this is more awful to oppressors when the perpetrator vanishes without a trace. They sit in their offices and palaces and quake" (23). As he demonstrates, terrorists killing and dying for their beliefs claim to act on behalf of a community and a cause, yet they are also asserting their autonomy. ${ }^{5}$ Razumov notices the same egotism in the revolutionaries in Geneva: "All revolt is the expression of strong individualism-ran his thought vaguely. One can tell them a mile off in any society, in any surroundings" (203). Using violence to benefit their community and risking their lives to attain fame and respect, terrorists achieve agency and solidarity in a single act. ${ }^{6}$

Razumov also seeks autonomy and community. He has absorbed the familiar ideology of meritocracy that one can achieve success through hard work. $\mathrm{He}$ is "a young man depending entirely upon the development of his natural abilities for his place in the world" (27). Assessing his opportunities, he thinks 
that academic distinction will lead to a career in the government bureaucracy. His individual achievement will allow him to become part of a community. Razumov avoids political activism because "his main concern was with his work, his studies, and with his own future" (16). Although he does not belong to a domestic or political circle, he too identifies with the Russian nation. Like Haldin, Razumov believes that he acts for the good of his country: "He was persuaded that he was sacrificing his personal longings of liberalism-rejecting the attractive error for the stern Russian truth. 'That's patriotism, he observed mentally" (35). He deplores the injustice of the autocratic regime, but he favors "Evolution not Revolution. Direction not Destruction. Unity not Disruption" (57).

Haldin shatters these aspirations. Discovering Haldin hiding in his rooms, Razumov thinks: “There goes my silver medal!" (20) He realizes that he could be imprisoned on mere suspicion of being associated with the assassin: "The police would very soon find out all about him. They would set about discovering a conspiracy. Everybody Haldin had ever known would be in the greatest danger" (23). Razumov "saw himself deported by an administrative order, his life broken, ruined and robbed of all hope" (24). Through no choice of his own, Razumov is implicated in Haldin's crime: "I am now a suspect,' he thought again" (61). He blames Haldin for destroying his plans: “Am I to let my intelligence, my aspirations towards a better lot be robbed of the only thing it has to go upon at the will of violent enthusiasts? You come from your province but all this land is mine-or I have nothing'" (54). Haldin deprives him of agency and a pathway to joining a community. As a result, Razumov disintegrates: "He had a distinct sensation of his very existence being undermined in some mysterious manner, of his moral supports falling away from him one by one" (65). Feeling trapped and alone, Razumov is overcome by "rage and fear" (64).

Despite his anger, however, Razumov feels a moral obligation to Haldin as a desperate man in great need of assistance. ${ }^{7}$ Weighing Haldin's claim against his own convictions, Razumov is "in conflict with himself" (33). He knows that Haldin is guilty: "'For it is a crime, he was saying to himself. 'A murder is a murder' " (28). Yet he feels dishonorable for betraying Haldin's personal trust. He considers his options: "I would save him if I could-but no one can do that-he is the withered member that must be cut off' " (35). Imagining Haldin's accusations, Razumov defends himself:

"What is a betrayal? They talk of a man betraying his country, his friends, his sweetheart. There must be a moral bond first. All a man can betray is his conscience. And how is my conscience engaged here; by what bond of 
common faith, of common conviction am I obliged to let that fanatical idiot drag me down with him? On the contrary-every obligation of true courage is the other way." (36)

If Haldin feels guilty for the deaths of innocent people, Razumov wrestles with his conscience for helping the police find Haldin. To save Haldin, Razumov would not only have to endanger himself but would also have to violate his own beliefs. Torn between approval of Haldin's cause and disapproval of Haldin's violence, resenting Haldin's intrusion and heeding Haldin's plea for help, Razumov becomes erratic.

Razumov fears arrest if he does not turn Haldin in, yet he dreads being responsible for someone's death. At first, he agrees to help Haldin escape, but the plan fails. ${ }^{8}$ Razumov is so distraught that he hallucinates a vision of Haldin's body lying in the snow. Only then does he decide to lead the police to Haldin. Knowing that he will be considered a suspect, Razumov asks his father, Prince K, to accompany him to the police. The nobleman gives Razumov his full approval: "Nobody doubts the moral soundness of your action'” (43). Voiced by an aristocrat, this judgment may seem self-serving, but it is consistent with the principles of our own time. Everyone is expected to report suspicious persons, activities, and objects. The families of terrorists are routinely interrogated. ${ }^{9}$ Despite Prince K's efforts to protect his son from the repercussions of an involuntary encounter with the assassin, the police exploit Razumov's vulnerability. Councillor of State Mikulin maneuvers Razumov into spying on expatriates in Geneva. Razumov is loath to cooperate. He wants to "retire," but Mikulin poses the unanswerable question: "Where to?" (82). Both the state and its opponents seize control of Razumov's life.

Conrad repeatedly attributes Razumov's frantic behavior to his loss of agency rather than feelings of guilt or remorse. As a dispossessed youth in an autocratic country, he has tried to achieve a measure of autonomy through academic achievement, and now he asks himself "if it were worthwhile to go on accomplishing the mental functions of that existence which seemed no longer his own" (66). Events beyond his control are to blame: "Again he experienced that sensation of his conduct being taken out of his hands by Haldin's revolutionary tyranny" (69). Autocracy and revolution are both tyrannical, and Razumov feels helpless: "He lost all hope of saving his future which depended on the free use of his intelligence" (70). His efforts seem futile: "three years of good work gone, the course of forty more perhaps jeopardized-turned from hope to terror, because events started by human folly link themselves into a sequence which no sagacity can foresee and no courage can 
break through. Fatality enters your rooms while your landlady's back is turned" (69-70). Today it may be easier to sympathize with Razumov's dilemma than with Haldin's decision.

As Razumov's plans collapse, he falls apart: "His strung up individuality had gone to pieces within him very suddenly" (72). When his agency is thwarted, he has no self: "The true Razumov had his being in the willed, in the determined future-in that future menaced by the lawlessness of autocracyfor autocracy knows no law_-and the lawlessness of revolution" (66). Deprived of his hopes for autonomy, he spirals out of control, and the rest of the novel deals with his disintegration. Losing his identity, he assumes the persona of Haldin's accomplice that the expatriates project onto him. ${ }^{10}$ His successful transition from being the informant to playing the terrorist illustrates why it is so hard to profile terrorists. Psychological and sociological profiles ignore the possibility of deceit and the effects of radicalization.

While most discussions of the novel's moral issues focus on the moment when Razumov becomes an informant, the climax of the novel, as Hagan suggests, is his later decision to reveal his role in Haldin's capture to the expatriates. They lionize Razumov as Haldin's accomplice, and Haldin's sister Natalia falls in love with him. By the time Razumov confesses, he is no longer in danger of the revolutionaries discovering that he is a government spy. It is their trust that makes his duplicity unbearable. Unwilling to continue dissembling before the state, before the revolutionaries, and before Natalia, he confesses his role in Haldin's capture first to Natalia, whom he loves, and then to the others, whom he despises. ${ }^{11} \mathrm{He}$ tells her that he has renounced his plan to seek revenge:

"Listen-now comes the true confession. The other was nothing. To save me, your trustful eyes had to entice my thought to the very edge of the blackest treachery. I could see them constantly looking at me with the confidence of your pure heart which had not been touched by evil things. Victor Haldin had stolen the truth of my life from me who had nothing else in the world. He boasted of living on through you on this earth where I had no place to lay my head on. She will marry some day, he had said. And do you know what I said to myself? I shall steal his sister's soul from her." (272)

With full knowledge that he will be punished by both the expatriates and the government, he refuses to occupy a false position any longer. This is a moral decision that allows Razumov to reassert his autonomy and regain his integrity. His confession unexpectedly wins him a place in the community as well. Some of the expatriates whom he has deceived come to respect him. As Sophia Antonovna explains: 
"There are evil moments in every life. [... .] Well, call it what you like; but tell me how many of them would deliver themselves up deliberately to perdition as he himself says in that book, rather than go on living secretly debased in their own eyes? How many? And please mark this-he was safe when he did it. It was just when he believed himself safe, and moreinfinitely more-when the possibility of being loved by that admirable girl first dawned upon him, that he discovered that his bitterest railings, the worst wickedness, the devil-work of his hate and pride, could never cover up the ignominy of the existence before him. There's character in such a discovery." (287)

If Sophia Antonovna can exonerate Razumov, can we?

Irving Howe could not. He was unforgiving, blaming Conrad for portraying the revolutionaries as caricatures of political commitment who are unworthy of Razumov's confession: "if indeed [the revolutionaries] are as contemptible as he supposes he can hardly believe them the proper agents of either Haldin's heritage or revenge" (520). Certainly, Peter Ivanovitch, the great "revolutionary feminist" (106), is the object of the language teacher's scorn. The language teacher is Conrad's narrator and a fully developed character who expresses his own opinions. He satirizes Ivanovitch's sensational story of his escape from Siberia (98) and mocks him for exploiting particular women while mouthing feminist slogans. Writing at the height of Cold War fear of Russia, Howe objected to this tone. He argued that there was

a serious failure in judgment; an equation of rulers and ruled, both of whom Conrad finds to be stained by "the cynicism of oppression and revolt." To assimilate the behavior of a Haldin to the behavior of a Czarist functionary is to indulge the middle-class smugness which afflicts Conrad whenever he decides to place his drama under western eyes. (519)

Conrad, however, does not equate rulers and ruled. He demonstrates that members of both groups seek community and autonomy, though their personal aims lead to incomparable political positions. As Razumov admits:

"In giving Victor Haldin up, it was myself after all whom I have betrayed most basely. [....] After all it is they and not I who have the right on their side. Theirs is the strength of invisible powers. So be it. Only don't be deceived, Natalia Victorovna. I am not converted. Have I then the soul of a slave? No! I am independent-and therefore perdition is my lot." (274) 
Explicitly agreeing with Haldin, Razumov sees the justice of Haldin's cause but adamantly refuses to endorse his methods. Although Howe criticized Conrad's unwillingness to champion the revolutionaries, the novel ends with Sophia Antonovna's sincere praise for the previously ridiculed revolutionary feminist, "Peter Ivanovitch is an inspired man" (289).

Both satirized and admired, Ivanovitch exemplifies Conrad's aesthetic of complexity. As Tekla says, "Peter Ivanovitch is the greatest genius of the century perhaps but he is the most inconsiderate man living" (117). Addison Bross suggests that some of Ivanovitch's contradictory qualities are based on Conrad's father, Apollo Korzeniowski. He devoted his life to Polish independence, but he was not a terrorist (Najder xv). Citing an untranslated portion of Korzeniowski's article "Poland and Muscovy," Bross argues:

Given his obsession with the mystical and moral force of the peasantry, his worship of his martyred wife, his obsession with a distant destiny that supposedly would emerge from the special insights of the genius-poets of Polish Romanticism, his turning away from the material conditions that needed to be changed to ameliorate the lives of the peasants he idealized, Korzeniowski is not far from a figure in Under Western Eyes-the raving "feminist," the admirer of peasants, Peter Ivanovich [...]. (Bross 93)

Bross points out that Korzeniowski maintained "a valued myth, one that identified the peasantry's mystic role in Poland's destiny. Furthermore, as regards military strategy, the myth strengthened and justified the insurrectionists' faith that an armed rising against Russia was feasible" (Bross 87). Bross questions the value of Korzeniowski's faith in his cause, arguing that he "possessed a mentality that has to be called fanatical" (78). If Korzeniowski achieved little despite his integrity, Ivanovitch is successful despite his faults. The story of his life is "translated into seven or more languages" (98), and he is "a "heroic fugitive' of world-wide celebrity" (102). Conrad knew that character and achievement are not necessarily aligned. The novel's epigraph attributes this knowledge to Natalia: "I would take liberty from any hand as a hungry man would snatch a piece of bread."

\section{CONRAD'S KNOWLEDGE OF TERRORISM}

In addition to portraying the various reasons that individuals become revolutionaries, Under Western Eyes casts light on terrorism as a tactic. As the language teacher says, Haldin's act is “an event characteristic of modern Russia in 
the actual fact: the assassination of a prominent statesman" (14). Russian revolutionaries not only assassinated particular individuals, but they were also willing to kill bystanders who happened to be near an exploding bomb. Analyzing the effect of this tactic, the historian Yuval Noah Harari argues that terrorists "produce a theatrical spectacle that they hope will provoke the enemy and cause him to overreact. Terrorists stage a terrifying spectacle of violence that captures our imagination and turns it against us" (164). The historical events on which Conrad based Haldin's act produced this kind of spectacle. Naming the victim "Mr de $\mathrm{P}$-," Conrad alludes to the assassination of Minister of the Interior Count Konstantinovitch de Plehve by the Social Revolutionary Organization of Combat in July 1904. Conrad grafts onto this incident the two-bomb plan used by the terrorist group Narodnaya Volya [The People's Will] in 1881 to assassinate Tzar Alexander II (Carabine, Western Eyes xxxvi). This group chose dynamite instead of pistols because of its "dramatic effect" (Jasanoff 73). When the bomb aimed at the Tsar's carriage hit only the driver, another bomb was thrown. This time the attack was fatal to the Tsar and the bystanders who rushed to his aid. Like the second bomber, Haldin is responsible for the deaths of innocent people. Although some revolutionaries scrupulously avoided endangering anyone except their target (Laqueur 83), Haldin throws his bomb into a crowd. He becomes a terrorist when he willingly kills innocent bystanders.

The killing of random victims was theorized in nineteenth-century Russia as an effective political tactic. In 1881 the International Anarchist Congress formally adopted a strategy of "propaganda by deed" (Jasanoff 73), a euphemism that justifies and minimizes violence by treating it as a means of communication. As Mikhail Bakunin, wrote, "We must spread our principles, not with words but with deeds for this is the most popular, the most potent, and the most irresistible form of propaganda" (qtd. in Jasanoff 72). "Deeds" need not be violent, but Bakunin's meaning was made explicit by others. Peter Kropotkin declared that "a single assassination or bomb could 'make more propaganda than thousands of pamphlets" (qtd. in Jasanoff 73). Both men were sources for Peter Ivanovitch (Carabine, Western Eyes $\mathrm{xl}$ ), who is Conrad's composite revolutionary leader. ${ }^{12}$ Ivanovitch himself commits no violence, but he incites others to act. As Laqueur notes, the "terrorist campaign conducted by Narodnaya Volya was essentially different from anarchist activities elsewhere in Europe, which were carried out [. . . by isolated individuals inspired by obscure ideals. Russian terrorism was both one aspect of the formation of a revolutionary socialist party and a symptom of a general crisis in Russian society" (38). Although Russian anarchists were social revolutionaries, not opponents of all forms of government, they could be called anarchists because they 
utterly opposed the current government and used violent methods to overthrow it. The name of one of the meeting places for anarchists in London was the Autonomie Club (Jasanoff 76), and the oxymoron embedded in the concept of an anarchist organization suggests that its members, like Haldin and Razumov, sought both autonomy and solidarity.

Just as Conrad refuses to portray Haldin and Razumov as opposites, he rejects the political alternatives of revolution and the status quo. ${ }^{13}$ As Rachel Hollander argues, "By reducing Razumov's existence to the extreme choice between revolution and autocracy, Conrad emphasizes the limitations of both political ideologies, and the possibility for a wholly new alternative" (8). Scathing contempt for autocracy was not enough to make Conrad advocate revolutionary violence. We might say that as the son of Polish patriots he hated everything Russian, including Russian revolutionaries. We could also take Conrad at his word in the "Author's Note" to Under Western Eyes when he explains that he wanted to convey the "senseless desperation provoked by senseless tyranny" (6). The novel shows how Russian autocracy fueled revolutionary anger and how the government recruited informants and punished conspirators. As the English language teacher says, "I saw then the shadow of autocracy lying upon Russian lives in their submission or their revolt" (89). He warns that autocracy's ruthlessness produces a reciprocal recklessness, giving the public reasons to fear terrorists as well as the police. The historian Richard English observes the same result in more recent cases: "It is worth remembering that state responses to terrorism almost certainly do more to shape the world and its politics than do non-state terrorist acts themselves" (3).

In Under Western Eyes the violence of revolutionaries both counteracts and exacerbates the violence of the state. Conrad portrays terrorists and government agents as counterparts, similar in their ruthless quest for power despite their antithetical ideologies. As Andrzei Busza points out, Razumov is caught between "the lawless state and its obverse: the lawless revolution" (131). The methods of both are brutal, and both abrogate the individual's autonomy in the name of a greater cause. The language teacher warns Natalia:

"The last thing I want to tell you is this: in a real revolution-not a simple dynastic change or a mere reform of institutions - in a real revolution the best characters do not come to the front. A violent revolution falls into the hands of narrow-minded fanatics and of tyrannical hypocrites at first. Afterwards comes the turn of all the pretentious intellectual failures of the time. [....] Hopes grotesquely betrayed, ideals caricatured-that is the definition of revolutionary success." (108) 
Although critics sometimes regard him as Conrad's mouthpiece, the language teacher is presented as the representative of Western, specifically English values. More than an observer, he befriends Natalia and her mother and plays a role in Natalia's relationship with Razumov. Offering impressions of the expatriate community from a distinctly Western perspective, he shows the reader how different the revolutionaries are from one another and how far their networks extend. He sympathizes with the revolutionaries' cause but distrusts their methods. His friendship with Haldin's mother and sister allows him to see admirable qualities in the bomber. At the same time, feeling none of the Russians' desperation, the language teacher emphasizes the social and political costs of revolution. This stance pleases neither liberal nor conservative critics.

Despite his denunciation of autocracy, Conrad has been branded a reactionary conservative. ${ }^{14} \mathrm{He}$ was open to this charge because he was unable to endorse liberal democracy without qualification. In "Autocracy and War," Conrad explained why democracy was unsuitable for Russia: "Western thought when it crosses her frontier falls under the spell of her Autocracy and becomes a noxious parody of itself" (44). Razumov also believes that Russia is unique and must go through its own process of reform and evolution (57). Ivanovitch expresses the same conviction: "Everything in a people that is not genuine, not its own by origin or development is-well-dirt. Intelligence in the wrong place is that. Foreign bred doctrines are that. Dirt" (164-65). He concludes, "for us at this moment there yawns a chasm between the past and the future. It can never be bridged by foreign liberalism" (165). This constellation of attitudes cannot be labeled radical or reactionary, liberal or conservative.

Perhaps the most comprehensive account of Conrad's political beliefs is Avrom Fleishman's classic study Conrad's Politics: Community and Anarchy in the Fiction of Joseph Conrad. Drawing support from Conrad's essays, especially the Preface to Nigger of the "Narcissus," Fleishman regards solidarity as the underlying value in Conrad's work: "The organicist ethic of allegiance to the concrete, popular community should be seen in contrast to the prevailing individualist ethic of self-direction, self-realization, and self-assertion" (69). Fleishman pits the community of Haldin's political faction against the individualism of Razumov's personal ambition. Writing in 1967, Fleishman alludes to Cold War attitudes when he positions his argument against readings that defend individualism:

To take a last case, Razumov, the hero of Under Western Eyes, has been read as a victim of the stifling effect of revolutionary politics on the free development of the individual. It is much truer to the complexity of that novel to see him attempting to find a balance among various allegiances-to per- 
sons, to state, to humanity at large-conflicting claims which pull him apart and ultimately destroy him because he has been reluctant to realize and act on the fundamental fact that human life is social, that there is nowhere for the individual to retire in isolation. (72)

Although he recognizes the conflicting claims on Razumov, Fleishman blames Razumov's inability to join a community on individualism. Fleishman condemns individualism as the root of anarchy and a cause of terrorism: anarchy is "that state of social decomposition at the opposite pole from organic community. This anarchy is already latent in the individual-individuality and anarchy are implicated in each other-and in the absence of an ordering community it springs into action as terrorism" (92). While Fleishman contrasts Haldin's social engagement with Razumov's isolation, the alternatives of community and anarchy are less prominent in the novel than the imperatives of community and autonomy for both characters. Fleishman's binary of community and anarchy casts Razumov, not the bomber, as the terrorist. Regarding Razumov as a self-serving informant, Fleishman indicts him for anarchy and terrorism. Regarding Haldin as the representative of a community, Fleishman praises him as an altruist and excuses his violent act as a sacrifice for his country. This conclusion is untenable today. The ubiquitous threat of terrorism has discredited justifications of violence in the name of a community.

\section{CONRAD'S POLITICAL HOPE}

Conrad was skeptical of democracy, but he was not without hope. It rings out in Natalia's vision for an alternative to the violence of the state and its opponents. Although she keeps her distance from Ivanovitch's circle of expatriates, her dedication to their cause is unquestionable. She defends her brother, telling the language teacher, "'Don't expect to understand him quite,' she said a little maliciously. 'He is not at all-at all-Western at bottom'” (88). Her devotion to her brother and the revolutionary cause gives weight to her disavowal of violence when she discourages Sophia Antonovna's tribute to his momentous act: "I told her I hoped to see the time when all this would be forgotten, even if the name of my brother were to be forgotten too" " (252). The language teacher answers, "You think of the era of concord and justice" (252), and she replies: "Yes. There is too much hate and revenge in that work. It must be done. It is a sacrifice-and so let it be all the greater. Destruction is the work of anger. Let the tyrants and the slayers be forgotten together and only the reconstructors be remembered"' (252). The veteran revolutionary Sophia Antonovna approves: " it is good for you to believe in love” (252). 
It is easy to dismiss their hope as the naiveté of women, but Russian women who had risked their lives in revolutionary protests expressed similar aspirations. According to the historian Richard Stites, "In the 1870's, the vocation of revolutionary was the only one open to women which would greet her as an equal, allow her talents fully to unfold, and permit her to rise to the top; there her energies, character, and skills were unlocked and put to use. At the very least, the revolutionaries proved that woman was capable of things undreamed of in the traditional view" (153). ${ }^{15}$ In Russia women helped plan and carry out terrorist acts. Over a third of the twenty-eight member Executive Committee of Narodnaya Volya, the group responsible for the assassination of Alexander II, were women (145). Most were from gentry-officer families and were well educated (145). By the 1870s about one-eighth of the known revolutionaries were women (148), and "individual for individual, women were more deeply involved than men: 'better fewer, but better,' as Lenin would have put it" (149). These women "set a precedent for the large numbers of women who joined the revolution in 1905 and 1917" (153).

Vera Figner was a member of Narodnaya Volya, yet later in life, she renounced terrorism:

"The violence engendered by the struggle arouses ferocity, brings out the beast, awakens evil impulses, and leads to acts of disloyalty. Humanitarianism and greatness of soul are incompatible with it. And in this sense, both the government and the party, joining so to speak in hand-to-hand combat, competed with one another in the process of corrupting everything around them. On its side, the party proclaimed that all methods were permissible in the struggle against the enemy, and that the end justified the means. It also established a cult of the bomb and the revolver, and canonized the terrorist. Murder and the gibbet captivated the imagination of our young people; and the weaker their nerves and the more oppressive their surroundings, the greater was their sense of exaltation at the thought of revolutionary terror." (qtd. in Stites 146)

Figner's humane ideal resembles Natalia's. Although Conrad discredits the hypocritical feminism of Peter Ivanovitch, Ivanovitch pays tribute to the importance of women in the revolutionary struggle: " But we have the Russian woman. The admirable Russian woman! [. . ] The greatest part of our hopes rests on women'" (97). Even though his praise is sanctimonious, the most admirable characters in the novel are women. Conrad endows Tekla, Sophia Antonovna, and Natalia with commendable qualities. As Maureen Fries 
observes, "They are, in fact, largely superior in industry, mind, political commitment, and social responsibility to any man in the novel" (63).

Despite the historical foundation for characters like Natalia and Sophia Antonovna, they seem false to some critics. Our habitual hermeneutics of suspicion seize on Conrad's irony and skepticism. Phyllis Toy, for example, argues that Natalia's hopes are like every other ideology: they reflect "a spiritual absolutism" that is "as insidious as any autocratic political rule" (51). Toy concludes, "And so even Nathalie's ardent, idealist faith in Utopian revolutionism, her adamant rejection of the world as it is in the name of a transcendent alternative, cannot escape Conrad's skeptical examination" (51). Similarly, after examining the changes in Natalia as Conrad revised the novel, Keith Carabine compares her to the assassinated minister de $\mathrm{P}$ -

her noble dream of "loving concord," shares de P-'s autocratic desire for a univocal utterance, which would silence the "multitude of men's counsel." Thus, from opposing impulses, neither can accept or endure "the irreconcilable antagonisms" they inherit, and which constitute for their creator the only "fundamental truth" of both his fiction and of life on earth. (Carabine, Life 172)

But Conrad was not always skeptical. While he subjected all ideologies to critical scrutiny, he thought that his method of presenting competing ideas fostered hope. In a 1901 letter to The New York Times "Saturday Review," he wrote, "The only legitimate basis of creative work lies in the courageous recognition of all the irreconcilable antagonisms that make our life so enigmatic, so burdensome, so fascinating, so dangerous-so full of hope!” (CL 2:348-49). Carabine acknowledges that Natalia also expresses Conrad's hope for the future:

Again, without her [Natalia's] "sweet" wisdom he would have had neither an anchor for that "spirit of piety towards all things human which sanctions the conceptions of a writer of tales"; nor would he, I suggest, have had the spirit to persist in his determination to "render the highest form of justice to the visible universe," whose "soil" as ever, is "soaked in blood, torn by struggles, watered with tears." (Carabine, Life 173)

Avrom Fleishman also sees hope beneath Conrad's skepticism:

It is enough to be left with the ideal of love, of hope for human community, however difficult it is to imagine its development out of modern states. The 
vision acts as an encouragement to change, and Conrad's is the most potent secular hope for the future to be found in modern literature. (242)

Although Fleishman thinks that Conrad hopes for community rather than the concord and justice that Natalia seeks, he sees that Conrad has a vision for the future.

Our skepticism has made us less hopeful than Conrad was, but in The Practices of Hope (2019) Christopher Castiglia challenges us to abandon the hermeneutics of suspicion. Taking a postcritical perspective, he encourages us to recover the imaginative dimension of literature through a disposition of hope. Hopeful reading, he explains, is not willed optimism; it is a way to envision political possibilities that do not yet exist:

Hope is the articulation of the origins of critique in imaginative idealism, self-consciously unachievable standards for living, tested and refined in the context of an as-yet-unreal world, against which real conditions inevitably come up short. Hope is what I would identify as the literariness of literature. It is also the thing without which social change is impossible. (4)

While Conrad deplores the failings of autocracy, revolution, and, to a lesser extent, democracy, he also projects positive alternatives. He registers the hypocrisy and cynicism of political life: "Russian simplicity often marches innocently on the edge of cynicism for some lofty purpose" (102), yet he offers more than irony, suspicion, and despair. He helps us imagine a better future. Through Natalia and Sophia Antonovna, the two most laudable characters in the novel, Conrad proposes that concord and justice should replace state and anti-state violence. Hoping that tyrants and terrorists alike will be forgotten, Natalia urges us to look beyond the destructors to the reconstructors.

Under Western Eyes animates Conrad's political knowledge through the resources of fiction. Specific circumstances, complex characters, and a plot that includes intentional and accidental events help readers absorb insights that contemporary research on terrorism corroborates. The number of critics who admire Haldin for assassinating a minister and condemn Razumov for leading the police to the assassin demonstrates that Conrad was able to humanize a terrorist and demonize a conscientious citizen. Showing that they are fundamentally similar in their desire for community as well as autonomy, he reminds the public and the police that terrorists cannot be profiled. The novel focuses on the particular circumstances that led to a revolutionary mindset in Russia and the particular factors that cause one man to throw a bomb into a crowd 
and another to become a government agent. As a result, the novel can be used as a casebook on terrorism today.

\section{NOTES}

1. Conrad's father made the same connection in "Poland and Muscovy": "My personal fate, like that which befell hundreds of thousands of my countrymen, would not give me the right to dwell upon it. But when thoughts, actions, lives, tortures, bloodshed, deaths of all those brethren taken together form the character of a particular epoch in the history of Poland; when that epoch towers above all that is most laudable in human history, I believe that I have the right to tell it" (Korzeniowski 87).

2. In 1981 Martha Crenshaw argued that the "limited data we have on individual terrorists [...] suggest that the outstanding common characteristic of terrorists is their normality" ("Causes of Terrorism" 390). When this finding is ignored, resources are misused, as noted by the Brennan Center for Justice at New York University Law School: "Congress must require that counterterrorism resource decisions be based on objective evaluation of the physical harm different groups pose to human life, rather than on political considerations that prioritize the safety of some communities over others" (Reitman 42). An FBI statement in 2018 agrees: "Even if the F.B.I. wanted to monitor this hate speech, they wouldn't have the resources, or any way to distinguish between those who talk and those who act" (Reitman 44).

3. More recent research confirms Hudson's reports. To anticipate terrorist acts, Erik J. Dahl argued in 2013, we need "the precise intelligence" that depends on "tips from the public, informants working for local law enforcement, and long-term surveillance of suspects" (183). The "specificity of tactical-level intelligence" is more important than "broad, strategiclevel intelligence" in convincing policymakers that there is an imminent threat and that action is thus imperative" (3). In an article published in 2000, Martha Crenshaw, widely recognized as an expert on terrorism, states: "Nevertheless, most analysts of terrorism do not think that personality factors account for terrorist behavior, nor do they see significant gender differences. One of the basic research findings of the field is that terrorism is primarily a group activity. It is typically not the result of psychopathology or a single personality type. Shared ideological commitment and group solidarity are much more important determinants of terrorist behavior than individual characteristics" ("Psychology of Terrorism" 409). Ten years later she said: "Many individuals are potential terrorists, but few actually make that commitment. To explain why terrorism happens, another question is more appropriate. Why does involvement continue? What are the psychological mechanisms of group interaction?" (Explaining Terrorism 49).

4. Keith Carabine argues that Haldin resorts to figurative speech to defend his actions (“Man's 'Ingenuity in Error'” 102).

5. Conrad's father conveys similar feelings in his article "Poland and Muscovy." Sentenced to exile in Siberia, Korzeniowski expresses pride in his sacrifice: "I was going to depart from my country: everything which quickens my heartbeat and everything I stand for would be torn away from me. Nevertheless I was not sad" (83). Exile "seemed as good a way to serve my country as any other. The sentence lay heavily on my breast, stifling my breath and 
thought; but at the same time it shone like a sign of merit, branded by the enemy but awarded by my country" (84).

6. Martha Crenshaw cites a study of the countervailing reasons people join terrorist groups: "Commitment is also motivated by ego-involvement. Individuals seek to maintain self-respect, the support of the peer group, and the sense of belonging that is heightened by a sense of shared risk" ("Psychology of Terrorism" 409).

7. Robert Hampson in Joseph Conrad: Betrayal and Identity argues that even though Razumov obeys the law, he feels guilty for "betraying" Haldin because "the narrative assumes bonds of human solidarity which transcend the laws of a given society: in attempting to keep within the latter, Razumov breaks the former" (191).

8. George Goodin argues that Razumov decides to help Haldin to protect himself: "Razumov's first decision is to preserve his neutrality, which he can best accomplish, he believes, by helping Haldin escape" (334).

9. See Mohammed Hafez (15-17).

10. Robert Hampson in Conrad's Secrets notes that others have made this point: "Apart from Levin [Yael Levin, Tracing the Aesthetic Principle in Conrad's Novels, New York: Palgrave Macmillan, 2008), 74], Terence Cave [“Joseph Conrad: The Revenge of the Unknown" in Keith Carabine, ed., Joseph Conrad: Critical Assessments, Mountfield: Helm Information, 1992] has written on how Razumov presents himself as a blank surface onto which other characters project meanings" (277, n. 21).

11. Although Razumov is not a revolutionary, his talk of confession echoes Conrad's father in "Poland and Muscovy." Calling his diary a Confession (88), Korzeniowski, like Razumov, offers a confession from the depths of his suffering. Despite an eight-month imprisonment and subsequent exile, his resolve is stronger than ever: the "greatness of those last days of entombed Poland has only one expression worthy of itself: a confession based on nothing but the life-giving Truth" (88).

12. Keith Carabine sees "aspects of Leo Tolstoy and several political dissidents-Prince Peter (né Pyotr Alexeyevich) Kropotkin (1841-1921), Rufin Piotrowski (1806-72) and Bakunin (1814-76)" in Peter Ivanovitch. Like him, Bakunin "championed women's rights (particularly in his 'Manifesto of the Russian Revolutionary Association to the Oppressed Women of Russia on Women's Liberation'” (Western Eyes xl).

13. Evelyn Cobley argues that the "parallel between hero and country" in Under Western Eyes preserves "the complexities of socio-political dilemmas. The technique creates ambiguities that do not permit the reader to side with one political system without making concessions to others, compelling him to appreciate both the strengths and the weaknesses of political alternatives" (377).

14. Stephen Ross summarizes the critical consensus: "Indeed, the notion that Conrad preached the superstitions of his age has guided rather than been challenged by all but the most recent inquiries into his attitudes toward everything from imperialism to feminism, revolution to sexuality, and guilt to globalization. He has been cast variously as (at best) a conservative in thrall to the ethic of his family's noble background; a pseudo-aristocratic reactionary; or (at worst) a jingoistic, racist social Darwinist" (3).

15. Hudson notes more recent examples of women who appreciated the equal opportunities terrorism offered them (57). 


\section{WORKS CITED}

Bross, Addison. “Apollo Korzeniowski's Mythic Vision: 'Poland and Muscovy,' 'Note A.'” The Conradian, vol. 20, nos.1-2, 1995, pp. 77-102.

Busza, Andrzei. "Under Western Eyes and 'The Theatre of the Real." Under Western Eyes: Centennial Essays, edited by Allan H. Simmons, J. H. Stape, and Jeremy Hawthorn, Rodopi, 2011, pp. 127-40.

Carabine, Keith. "Introduction." Under Western Eyes, edited by Roger Osborne and Paul Eggert, Cambridge University Press, 2013, pp. xxvii-liii.

—. The Life and the Art: A Study of Conrad's Under Western Eyes. Rodopi, 1996.

—. "Man's 'Ingenuity in Error': Construing and Self-Deception in 'Julius Caesar' and Under Western Eyes. The Conradian, vol. 10, no. 2, 1985, pp. 94-115.

Castiglia, Christopher. The Practices of Hope: Literary Criticism in Disenchanted Times. New York University Press, 2017.

Cobley, Evelyn. "Political Ambiguities in Under Western Eyes and Doktor Faustus." Canadian Review of Comparative Literature, 1983, pp. 377-88.

Conrad, Joseph. "Autocracy and War." The North American Review, vol. 181, 1905, pp. 33-55.

- Collected Letters of Joseph Conrad. Vol. 2, edited by Frederick R. Karl and Laurence Davies, Cambridge University Press, 1986.

—. Under Western Eyes. Edited by Roger Osborne and Paul Eggert, Cambridge University Press, 2013.

Crenshaw, Martha. “The Causes of Terrorism.” Comparative Politics, vol. 13, no. 4, 1981, pp. 379-99.

_. Explaining Terrorism: Causes, Processes, and Consequences. Routledge, 2011.

—. "The Psychology of Terrorism: An Agenda for the Twenty-first Century." Political Psychology, vol. 21, no. 2, 2000, pp. 405-20.

Dahl, Erik J. Intelligence and Surprise Attack: Failure and Success from Pearl Harbor to 9/11 and Beyond. Georgetown University Press, 2013.

Fleishman, Avrom. Conrad's Politics: Community and Anarchy in the Fiction of Joseph Conrad. The Johns Hopkins Press, 1967.

Fries, Maureen. "Feminism-Antifeminism in Under Western Eyes." Conradiana, vol. 5, 1973, pp. 56-65.

Goodin, George. "The Personal and the Political in Under Western Eyes." NineteenthCentury Literature, vol. 25, 1970, pp. 327-42.

Hafez, Mohammed M. "The Ties that Bind: How Terrorists Exploit Family Bonds." CTC Sentinel, vol. 9, no. 2, 2016, pp. 15-17.

Hagan, John. "Conrad's Under Western Eyes: The Question of Razumov's 'Guilt' and 'Remorse." Studies in the Novel, vol. 1, 1969, pp. 310-22.

Harari, Yuval Noah. 21 Lessons for the 21st Century. Spiegel \& Grau, 2018.

Hampson, Robert. Conrad's Secrets. Palgrave Macmillan, 2012.

—. Joseph Conrad: Betrayal and Identity. St. Martin's Press, 1992.

Haugh, Robert F. "Joseph Conrad and Revolution." College English, vol. 10, 1949, pp. 273-77.

Hollander, Rachel. “Thinking Otherwise: Ethics and Politics in Joseph Conrad's Under Western Eyes." Journal of Modern Literature, vol. 38, no. 3, 2015, pp. 1-19. 
Houen, Alex. Terrorism and Modern Literature, from Joseph Conrad to Ciaran Carson. Oxford University Press, 2002.

Howe, Irving. "Order and Anarchy: The Political Novels." Kenyon Review, vol. 15, 1953, pp. 505-21.

Hudson, Rex. The Sociology and Psychology of Terrorism: Who Becomes a Terrorist and Why? Federal Research Division, Library of Congress, 1999.

Hueffer, Ford Madox. English Review, December 1911-March 1912, pp. 69-83. Rpt. in Vincent Sherry, ed., Conrad: The Critical Heritage, Routledge \& Kegan Paul, 1973, pp. 240-50.

Jasanoff, Maya. The Dawn Watch: Joseph Conrad in a Global World. Penguin, 2017.

Karl, Frederick R. "The Rise and Fall of Under Western Eyes," Nineteenth-Century Fiction, vol. 13, no. 4, 1959, pp. 313-27.

Korzeniowski, Apollo. "Poland and Muscovy." Conrad Under Familial Eyes, edited by Zdzisław Najder, translated by Halina Carroll Najder, Cambridge University Press, 1983, pp. $75-88$.

Laqueur, Walter. The Age of Terrorism. Little, Brown and Company, 1987.

Najder, Zdzisław. "Introduction." Conrad Under Familial Eyes, edited by Zdzisław Najder, translated by Halina Carroll Najder, Cambridge University Press, 1983, pp. xi-xxi.

Pall Mall Gazette, 11 October 1911, p. 5. Rpt. in Vincent Sherry, ed., Conrad: The Critical Heritage, Routledge \& Kegan Paul, 1973, 227-28.

Reiss, Tom. "The True Classic of Terrorism." New York Times Book Review, Sept. 11, 2005, p. 35 .

Reitman, Janet. "State of Denial." New York Times Magazine, Nov. 11, 2018, pp. 38-49, 66-68.

Ross, Stephen. "The Ancien Régime and Fetishistic Politics in The Nigger of the 'Narcissus.'” Conradiana, vol. 39, 2007, pp. 3-16.

Stites, Richard. The Women's Liberation Movement in Russia: Feminism, Nihilism, and Bolshevism, 1860-1930, Princeton University Press, 1978.

Toy, Phyllis. "Joseph Conrad's Under Western Eyes: The Language of Politics and the Politics of Language." Joseph Conrad: East European, Polish and Worldwide, edited by Wiesław Krajka, East European Monographs, 1999, pp. 41-59. 